\title{
日本薬学会の取り組み 日本学術会議との協働
}

\section{高倉喜信}

日本薬学会は日本学術会議と連携してこれまで様々なテーマで公開シンポジウムを共同主催し、科学的な観点か らの情報発信に努めてきた。現在、新型コロナウイルス感染症COVID-19が世界中で流行しているが、対応策の切 り札の一つとして新たに開発されたmRNA ワクチンの接種が進められている。COVID-19を終息させるためには日 本がコミュニティーとして「集団免疫」を獲得する必要があるが、そのためにはワクチンに対する正しい理解を共 有し、一人ひとりがワクチン接種についてきちんと選択できることが重要と考えられる。そこで、日本薬学会と日本 学術会議は協働して新型コロナワクチンに関する基本的な科学的情報を国民に分かりやすく、タイムリーに発信し、 我が国のワクチン接種を円滑に推進することを目的に 2021 年 4 月および7月に公開シンポジウムをWeb 開催した。

新型コロナワクチン、日本薬学会、公開シンポジウム

\section{はじめに}

日本薬学会は、1880年（明治13年）4月に創立 された 140 年以上の歴史を持つ学術団体である。 現在、約 16,000 名の個人会員、凡そ200の団体・ 企業の賛助会員を有し、「薬学」という共通のキー ワードのもと、大学、企業、医療機関、各種研究 機関、行政機関等、広範な専門領域からの会員に より構成されている。

学術活動の中心は学術大会であり、年に一度開 催される年会は、学会創立当時から継続的に開催 されてきた。2020年3月には節目となる第 140 年 会が京都で開催された。また、各専門領域別の 10 の部会および全国を地域別に8つに分けた支部を それぞれ縦糸・横系として設け、学術活動を展開 している。部会は、薬学研究の高度化と次世代を 担う優れた人材の育成を共通の主要課題とし、シ ンポジウム、フォーラム、研究会などを通じ、各 部会の特長に合わせた活動を進めている。一方、 支部は、各地域の会員と日本薬学会との接点の場 として、地域薬剤師会との交流をはじめ地域に密 着した積極的な事業展開を行っている。
また、複数の常置委員会を設置し、広範な学術 活動を進めている。中でも学術誌の発行は重要な 活動であり、英文3 誌（Chem. Pharm. Bull.（創刊 1953年)、Biol. Pharm. Bull. ( 同 1978年)、BPB Reports（同2018年））、和文 1 誌（薬学雑誌（同 1881年））を発行し、併せて学会の情報誌として 会誌ファルマシア（同1965年）を発行している。 国際交流にも積極的に取り組んでおり、国際薬学 連合 (FIP) やアジア医薬化学連合 (AFMC) との 連携やドイツ、韓国、カナダの薬学会との交流な どを推進している。さらに文部科学省、厚生労働 省と連携した活動も活発に行っている。

以上のような一連の学術活動の中で、日本薬 学会は日本学術会議との協働事業としてこれまで 種々のシンポジウムを共同主催してきた1。あらゆ る分野の科学者を内外に代表する機関である日本 学術会議と連携してシンポジウムを開催すること は日本薬学会の学術情報発信の重要な柱の一つと 考えている。本稿では2021年度に開催した新型コ ロナウイルスワクチンをテーマとして開催した二 つの公開シンポジウムを紹介する。 


\section{公開シンポジウム「くりのエキスパートが語る “よくわかる新型コロナウイルスワクチン”」}

2019年 12月に中国武漢において新型肺炎が 確認され、後にその原因ウイルスとしてSARSCoV-2が同定された。その後、この新型コロナウ イルスの感染は世界中に急速に拡散した。WHO はこの感染症をCOVID-19 と命名し、2020年3 月11日にパンデミック宣言を発出した。一方、 SARS-CoV-2のゲノムの塩基配列が解明された直 後から感染を抑制することができる mRNAワクチ ンの開発が開始され、ゲノム解析後 2 か月余りで 臨床試験に着手するなど急ピッチで実用化が進め られた。その結果、非常に優れたワクチン効果が 確認され、新型ウイルス発見からわずか 1 年しか 経過していない2020年 12 月にファイザーおよび モデルナの mRNAワクチンが米国で認可され接種 が開始された

その後世界各国で承認が続き、我が国でもファ

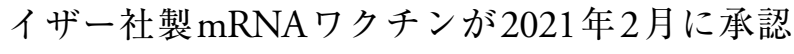
されたのを受けて医療従事者を対象にワクチン接 種が開始され、4月からは65歳以上の高齢者や基
礎疾患のある方などに接種対象が広がった。新型 コロナワクチンの接種は、COVID-19終息への切 り札のひとつと考えられているが、mRNAワクチ ンはこれまで普及しているワクチンとは全く異な る原理に基づいている。高い有効性が報告されて いるが、一方で、まれではあるが重篤な副反応の 事例も報告されている。COVID-19を終息させる ためには日本がコミュニティーとして「集団免疫」 を獲得する必要があるが、そのためにはワクチン に対する正しい理解を共有し、一人ひとりがワク チン接種についてきちんと選択できることが重要 と考えられる。そこで、新型コロナワクチンに関 する基本的な科学的情報を国民に分かりやすく、 タイムリーに発信し、我が国のワクチン接種を円 滑に推進することを目的に4月24日に日本薬学 会と日本学術会議の共同主催で公開シンポジウム 「くすりのエキスパートが語る“よくわかる新型コ ロナウイルスワクチン”」を開催した。本シンポジ ウムでは、以下のプログラムでmRNAワクチンに 関する基本的な内容を薬学研究者や薬剤師等、薬 学の専門家6名が解説した。6つの講演の主旨は本 号に掲載されているのでご参照いただきたい。

\section{プログラム}

\section{総合司会}

入江徹美（日本薬学会理事、日本学術会議連携会員、熊本大学大学院生命科学研究部（薬学系）教授）

\section{開会の辞}

佐々木茂貴（日本薬学会会頭、長崎国際大学教授）

望月眞弓（日本学術会議会員・副会長、慶應義塾大学名誉教授）

\section{趣旨説明}

高倉喜信（日本薬学会顧問（前会頭）、日本学術会議連携会員、京都大学薬学研究科教授）

座長 : 安原眞人（日本学術会議連携会員、帝京大学薬学部特任教授）

「そもそもワクチンとは?」

多屋馨子（日本学術会議連携会員、国立感染症研究所 感染症疫学センター室長）

「新型コロナワクチン : 広がるモダリティ」

井上貴雄 (国立医薬品食品衛生研究所 遺伝子医薬部長) 


\section{「mRNA 医薬・ワクチンとは何か」}

位高啓史 (東京医科歯科大学生体材料工学研究所 生体材料機能医学分野教授)

座長 : 合田幸広（日本学術会議連携会員、国立医薬品食品衛生研究所所長）

「ワクチン接種に関してお守りいただきたいこと」

石井伊都子 (日本薬学会副会頭、日本学術会議連携会員、千葉大学病院薬剤部長・教授)

「抗体検查って何？一感染防御に関わる抗体とその検查方法の特徵一」

石井明子（国立医薬品食品衛生研究所生物薬品部長）

\section{「これからの新型コロナウイルスワクチンの開発・評価について」}

荒木康弘（医薬品医療機器総合機構（PMDA）ワクチン等審査部長）

\section{閉会の辞}

入江徹美（日本薬学会理事、日本学術会議連携会員、熊本大学大学院生命科学研究部（薬学系）教授)

各講演はライブ配信と共に録画したものを5月 15日までストリーミング配信したが、予想をはる かに超える 1,542名（薬学会会員363名）の方々に 事前参加登録いただき、ライブ配信においての最 大同時アクセス人数は 734 名であった。視聴者は 幅広い年齢層に渡り、60歳以上の視聴者も多かっ た。ライブ配信中に案内したアンケートには、大 学関係者、医療関係者、企業からの視聴者を中心 に147名から回答が寄せられ、「大変参考になっ た」61\%、「参考になった」38\%と高い評価が得ら れた。難易度については、「普通」52\%、「簡単・ やや簡単」7\%であったが、一方で「やや難しい」 34\%、「難しい」7\%と感じた視聴者も一定数いた (図1）。また、以下のような意見・感想 (自由記述) が寄せられた。

・大変勉強になった。分かりやすかった。ワク チンへの理解が深まった。

-タイムリーな話題を専門的、科学的にかつ大 変分かりやすく解説されていた。

・一般向けには少し難しい内容もあった。

・エビデンスやデー夕に基づいた解説が良かった。

・専門外の聴衆も多いことにも配慮してほしかった。

・オンラインセミナー形式でじっくりと聴講で
きた。オンデマンド配信も良かった。

・今後もこのような社会的に意味のある一般向 けの企画を期待している。

また、Webで受け付けた事前質問に加えて当日 も多くの質問が寄せられ、新型コロナワクチンに 対する関心の高さが実感された。その後、質問へ の回答を3回に分けて薬学会ホームページで公開 した ${ }^{3-5}$ 。アクセス数は非常に多くなっており、ワ クチンに対する理解の一助となっていれば幸いで ある。

アンケート結果（図 1 および意見・感想（自由記 述））は日本薬学会会誌「ファルマシア」57巻7号 680頁-681頁「アップトゥデイト」より引用一部 改変。

\section{公開シンポジウム 「新型コロナワクチンを正しく知る」}

2021年 2 月に始まった我が国での新型コロナワ クチンの接種は精力的に進められ、6月には大学 • 職域接種が始まり接種の対象者は $18 \sim 64$ 歳へと 拡大された。また、一日あたりの接種回数 100 万 回の目標が達成されたことも報じられ、多くの国 


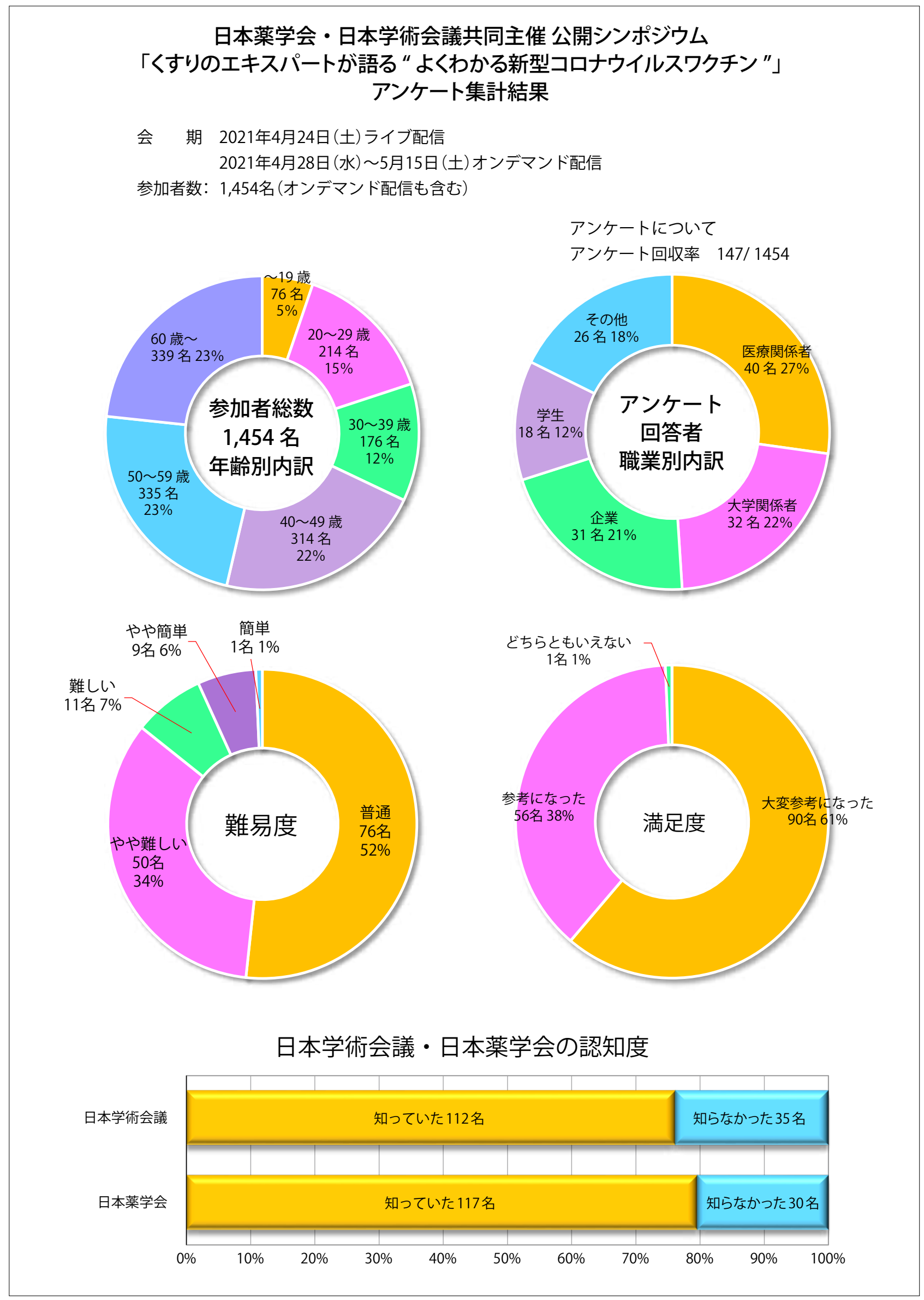

図1 
民にワクチン接種への理解が浸透してきたと思わ れた。しかしながら、依然として副反応への不安 などからワクチン接種に消極的なポピュレーショ ンも相当数いると考えられる。また、妊婦や小児 に対するワクチン接種に関する情報は十分に国民 に共有されているとは言えない。そこで新型コ ロナワクチンに関する2回目の公開シンポジウム 「新型コロナワクチンを正しく知る」を7月17日に 日本薬学会、日本学術会議、日本医学会連合との
共同主催で開催した。

1 回目のシンポジウムではmRNAワクチンにつ いて基本的な理解を促すことが目的であったが、 2 回目のシンポジウムでは、産婦人科および小览科 の医師の立場からの講演、さらにはパネルディス カッションを企画し、より広範な観点から新型コ ロナワクチンのベネフィットとリスクに関する最 新情報の発信と双方向での対話を目的に以下のプ ログラムでシンポジウムを開催した。

\section{プログラム}

\section{総合司会}

武田洋幸（日本学術会議会員 ·第二部部長、東京大学大学院理学系研究科教授）

\section{開会挨拶}

望月眞弓（日本学術会議会員・副会長、慶應義塾大学名誉教授）

\section{「mRNA ワクチン・mRNA 医薬品とは何か ? 」}

位高啓史 (東京医科歯科大学生体材料工学研究所生体材料機能医学分野教授)

\section{「新型コロナウイルス感染症とワクチンによる予防」}

西順一郎（鹿児島大学大学院医歯学総合研究科微生物学分野教授）

\section{「新型コロナワクチンの副反応」}

伊藤澄信（順天堂大学医学部客員教授）

\section{「妊娠と新型コロナウイルスワクチン接種〜その必要性と安全性を中心に〜」}

川名敬（日本大学医学部産婦人科学系産婦人科学分野主任教授）

\section{「子どもへの新型コロナワクチン」}

森内浩幸 (長崎大学大学院医歯薬学総合研究科 $\cdot$ 小巟科教授)

「パネルディスカッション」モデレーター

神田玲子（量子科学技術研究開発機構量子生命・医学部門放射線医学研究所副所長）、参加者 医療ジャーナリスト、学生

\section{閉会挨拶}

丹下 健（日本学術会議会員・第二部副部長、東京大学大学院農学生命科学研究科教授）

シンポジウムでは事前質問を受け付けて各講師 にそれぞれ講演中に回答いただいた。当日の質問 についてはパネルディスカッションの中で回答し ていただいた。また、パネルディスカッションで は医療ジャーナリストと現役の大学生数名に参加
していただき、一般の方々がワクチンに関して疑 問に感じられていると思われる種々の事項に関す る質問をしてもらい議論を深めた。シンポジウム はYouTubeでLive配信し、終了後も1週間程度は 視聴できるよう配慮した。同時視聴者数は最大時 


\section{公開シンポジウム「新型コロナワクチンを正しく知る」(2021.7.17.)}

\begin{tabular}{|lr|}
\hline 同時視聴者数（最大） & 863件 \\
再生数 (7/25までの累計) & 9,794 件 \\
\hline
\end{tabular}

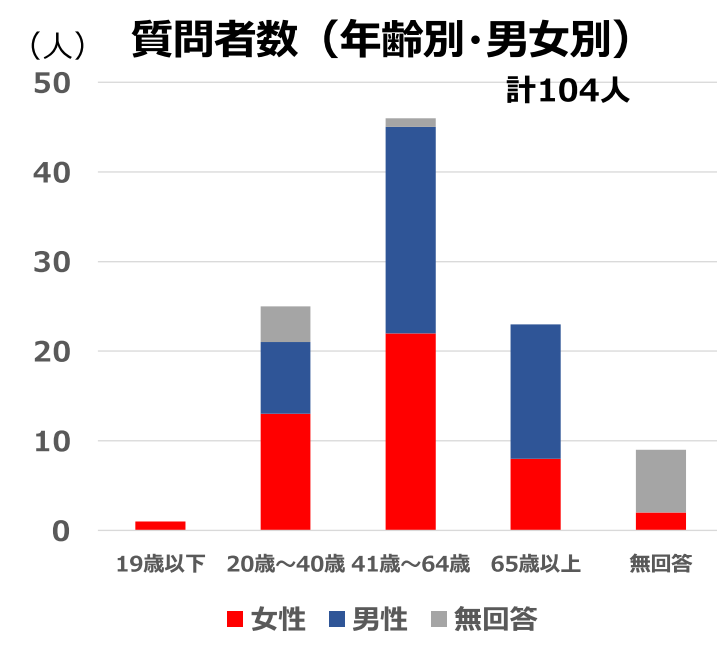

質問者の分類 (177問)

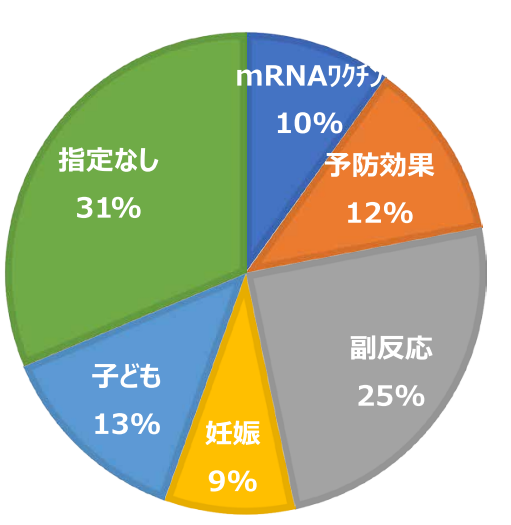

図2

で863件、再生数は9,794件であった（図2）。104 人から寄せられた177の質問では、副反応に関す る質問が最も多かった。なお、講演資料はPDF形 式でダウンロードができる。また、講演時に回答 できなかった質問への回答は、日本学術会議ホー ムページに順次公開される予定である。

\section{おわりに}

以上、2021年度に日本薬学会が日本学術会議と 共同主催した二つの新型コロナウイルスワクチン に関するシンポジウムの概略を紹介した。今後は COVID-19終息に向けてワクチンとならび重要な 柱の一つとなる治療薬の開発状況などについても 取り上げたい。

日本学術会議の薬学系の会員、連携会員の多 くは日本薬学会会員であり、日本薬学会と日本学 術会議は連携して活動しやすい環境にある。こ れまでにも年 2 ～ 3 回は日本薬学会と日本学術 会議は共同して公開シンポジウムを主催してき
た。今後も日本薬学会は日本学術会議と連携して COVID-19に関するテーマのみならずタイムリー な話題に関する情報発信に努める所存である。

\section{参考文献}

1. https://www.pharm.or.jp/gakujutsukaigi/teikei.shtml

2. Calvalho T. et al, The first 12 months of Covid-19. Nature Rev Immunol. 21, 245 (2021).

3. https://www.pharm.or.jp/news/news_20210531443.html

4. https://www.pharm.or.jp/news/news_20210712462.html

5. https://www.pharm.or.jp/news/news_20210817471.html

\section{PROFILE}

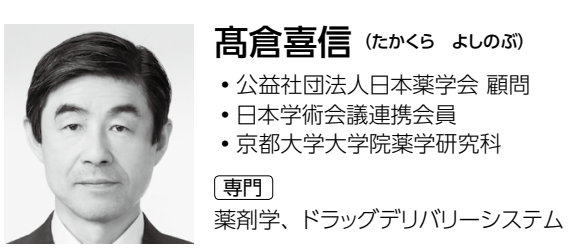

